The list, nature, and directions in changing the business processes of public corporations due to digital transformation have been determined. The main digital technologies that are used by public corporations operating in the basic sectors of the national economy were grouped. It has been proven that one of the most important criteria for digital transformation is the level of information transparency.

A morphological matrix of digital transformation of public corporations has been built and the positions of the latter in the process under study have been determined. Based on the results of the matrix assessment, it was concluded that the most attention is attracted by the digitalization processes in corporations-outsiders. This is because this position is characterized by a high level of digital maturity but a low level of transparency. To ensure a high level of transparency, it seems appropriate for these companies to introduce new digital technologies.

This paper analyzes those endogenous and exogenous factors that promote or block the process of introducing digital technologies in public corporations. It was found that at the level of public corporations, there are significant resource constraints, which are manifested in the lack of funds for the introduction of digital technologies. Another significant obstacle is the psychological barriers associated with the unwillingness to use digital technologies in the work process.

The generalization of the efficiency indicators of business processes and criteria for factor conditions of digital transformation has made it possible to identify the main components of the system model of digitalization of public corporations. Considering the above, an authentic system model of digitalization of the public corporate sector is proposed. It seems appropriate to use the model to determine the effect of the introduction of digital technologies in the public corporate sector

Keywords: public corporations, digitalization, business processes, digital transformation, blockchain, digitalization system model

\section{IMPROVING METHODS FOR EVALUATING THE RESULTS OF DIGITIZING PUBLIC CORPORATIONS}

\author{
I gor Du n a y e v \\ Corresponding author
}

Doctor of Science in Public Administration, Professor*

Director

Public Organization «Research Center of Economic and Legal Decisions in the Field of Application of Distributed Registry Technologies»

E-mail: i.dunaev@karazin.ua

A l eks a nder K ud

General Director

«Simcord Company» LLC

Otakara Yarosha str., 18 a, Kharkiv, Ukraine, 61045

Mykola Latynin

Doctor of Science in Public Administration, Professor*

Alisa Kosenko

$\mathrm{PhD}$, Associate Professor*

Victor Kosenko

$\mathrm{PhD}$, Associate Professor, Director «Kharkiv Business School» LLC

50-richchia Peremohy str., 68, Tsyrkuny vil., Kharkiv dist.,

Kharkiv reg., Ukraine, 62441

I gor Kobzev

$\mathrm{PhD}$

Department of Information Technologies and Control System**

* Department of Economic Policy and Management**

** Educational and Research Institute «Institute of Public Administration»

V. N. Karazin Kharkiv National University Svobody sq., 4, Kharkiv, Ukraine, 61022

\section{Introduction}

Globalization, the rapid development of information technology in all areas of life, the spread of telecommunications technology and increasing Internet coverage, the interaction between different participants in the online market have led to the rapid development of the digital economy. The manufacturability and competitiveness of the leading national economies have become characterized by the level of development of digital transformation, or so-called digitalization, and the share of the digital economy sector. Under current condi- tions, digitalization is the main factor in global growth, which provides a number of benefits for the national economy as improving productivity, saving time, creating a new demand for new products and services, and others. Digital data can also be used as a resource for production, which will change the structure of the economy from the traditional market to digital and will change all sectors of the economy. Significant changes will be made by the public and private, actual, productive, and non-productive, financial, and service sectors. These changes will ultimately help increase the competitiveness of the country's economy and improve the quality of life. 
Global corporations are focusing more and more on developing and implementing their digital transformation strategy. However, public corporations lag far behind businesses in this regard, necessitating their transformation into today's realities.

The transformational processes that are taking place with the advent of the new millennium require a reformatting of the management of the national economy and its public sector. The main driving force of the public part of the economy is public corporations, which provide financial, social, energy, food, transport component of national security, which, in turn, form the general level of economic security of society.

Under the conditions of rapid development of digital technologies and the formation of a significant array of data that systematically characterize the public and trends of public corporations, there is a need to improve methods of analysis and evaluation of the digital transformation of these types of structures.

In this regard, the establishment of the systemic impact of digital technologies on the efficiency of public-owned corporations deserves special attention.

Considering the need to urgently rethink the enterprises' functioning in the digital age, it is important to improve methods for assessing the digitalization results of public corporations.

\section{Literature review and problem statement}

Many scientific works have addressed the issues related to the digital economy development and transformation processes, among which the vast majority focus on the problems of realization of the concept of the digital economy and social development.

Paper [1] reports the results of research on the current level of digitalization of social-economic development of the territory and its transformational potential. A list of indicators for assessing the digital quality of life has been developed, which provides a basis for determining promising areas in digitalization policy. In addition, the features of the impact of digital technologies on the transformation of existing business are identified, software products for managing business transformation processes are identified. The proposed ideas were logically continued in a study [2], which identified the impact of relevant technologies on the transformation of the existing linear business model into a digital one. Despite the high value of these works, they remain unresolved issues of adaptation of developed methods to different conditions of economic activity. One of the options to overcome this problem may be, firstly, to create a universal model of digital transformation, or, secondly, to narrow the study to the operating conditions of specific businesses.

These critical provisions were used in study [3], which proved that the need to use digital technologies to develop and implement new business models forces companies to re-evaluate existing opportunities, structures, and culture. This, in turn, allows determining, which technologies are relevant and how they will be used in organizational processes and business proposals. The cited paper defines that digital transformation should be a top priority for management and a defining feature of corporate business strategy and that by implementing digital technologies, firms can gain benefits on the path to transformation. Given the relevance and practical value of the study, it should be noted that any transformational changes, including on the way to high digital technologies, are experiencing some resistance. All this suggests that an in-depth study of the existing barriers that are a prerequisite for any change is appropriate.

This very approach is the basis of study [4], which identifies obstacles to digital transformation and proposes a new strategy "Strategic Action", which can be useful for manufacturing companies to succeed in the process of digital transformation. The limitation of this approach is to use only the national aspects of strategic development based on digitalization, at a time when globalization is actively taking place. Thus, it is especially important to study international experience on the subject.

Accordingly, important is study [5], which shows how entrepreneurs gain international experience in the physical and digital business environment and how this experience affects the recognition and use of international opportunities.

In a slightly different aspect, the processes of digitalization are considered in study [6], which attempted to determine the degree of impact of digital transformation on value creation. The study concludes that the concepts of technological entrepreneurship and technological expansion are part of the dynamic opportunities that help implement digital innovation at the national level. The authors hypothesize that all digital innovations should be supported by the demand for relevant skills and should be integrated into the innovation cycle. A similar scientific opinion can be traced in study [7]. Guided by theories of innovation dissemination, technical changes based on competencies and professional skills, the authors put forward a hypothesis similar to the previous study. The article introduces a new concept, "corporate digital divide", a phenomenon that has not been studied in detail in previous studies. The concept of the digital divide is explained by studying data on the relative dynamics of digital skills needed by companies. Empirical results provide interesting insight and encourage a rethinking of the corporate digital divide through the causal links between competence accumulation and digital technological change. Accordingly, it is concluded that this will, in turn, determine the conditions necessary for forecasting demand shocks for digital competencies in labor markets. The further development of digital technologies and the protection of related data requires the study of the issue of corporate digital responsibility. However, in the considered works the authors do not touch upon the issues of corporate information security and digital responsibility.

Unlike others, [8] considers corporate digital responsibility as a new concept, where it is defined as a set of common values and norms that govern the organization's activities on the four main processes related to digital technology and data. These processes include technology creation and data collection, operation and decision-making, verification and impact assessment, and technology and data improvement. Defines how to manage behavior that is compatible with corporate digital responsibility in terms of organizational culture. The article presents an important concept of corporate digital responsibility and opens new horizons of research. Today's issues of corporate digital responsibility are widespread, covering consumer, organizational and social aspects. This gives grounds to say that the continuation of research in this area is important and extremely necessary. 
Summarizing research in the field of digitalization, in [9], the team of authors substantiated the principles of building antitrust regulation of the economy in a digital economy. The paper proves that imbalances and imbalances in the financial market as a result of the introduction of new information technologies are a manifestation and consequence of the course and system unity of the stages of the process of turnover of financial resources in competitive markets. It is established that in the digital economy, greater systemic unity will be achieved through the use of digital assets in economic practices. This approach is somewhat one-sided in terms of determining the impact of digital assets on the socio-economic development of the enterprise, considered in the context of anti-monopolization of the economy.

Research [10] tackled this problem by rethinking management in the digital age. The authors propose a model of corporate governance based on strategic management as a solution to pressing problems. Among the highlighted issues are those faced by consumers, employees, and other important stakeholders due to the excesses of the digital business. The paper emphasizes the true disclosure of information, increased transparency, improved fair distribution of organizational resources, and increased trust.

It should also be noted that digital technologies directly affect the way public authorities are exercised, in which the interactions between the subject and the object of work (namely, property and information) over the exercise of authority are gradually changing. They are increasingly influencing all management processes in large public-owned corporations and are already becoming the norm for managing financial and material resources at all levels. These are numerous procedures and traditional operations that have been introduced in public-owned enterprises long ago and that need to be digitally updated. Moreover, with regard to the railway sector, all public railways in other countries are now rapidly trying to modernize their management so as not to lose market share in the transport markets and devalue the value of their tangible assets. This unconditional global trend is placing growing demands on the quality of public administration and providers of relevant high-tech and digital solutions. One of the most promising digital solutions is considered to be solutions based on distributed registry technology (blockchain) and, in particular, decentralized registries and decentralized platforms on the blockchain [11]. Despite the traditional management inertia in any public-owned corporation, they have great potential to become a digital basis for the main thing - to restore trust between independent participants in the public management of the public corporation. Which, in turn, will certainly be an impetus for the development of public services [12,13].

According to the review results [1-13], it can be concluded that most of the scientific works are devoted to the study of digitalization at the national level, as well as the transformation processes of business and production structures. It is established that the analysis, and accordingly the evaluation of the effectiveness of digital transformation of structures of different forms of ownership, is paid insufficient attention due to the lack of clear methodological provisions of this process. Therefore, the improvement of methods for evaluating the results of digitalization of public corporations is relevant and requires more careful study.

\section{The aim and objectives of the study}

The study aims to improve methods for evaluating the results of the digitalization of public corporations. Achieving this goal will provide an opportunity to model the joint interaction of all elements of digitalization of the public corporate sector, which can create the conditions for the success of the digital transformation.

To achieve this goal, the following tasks were set:

- to determine the list, nature, and directions of changes in the business processes of public corporations due to digital transformation;

- to single out indicators of management efficiency of the business processes changing as a result of digitalization;

- to analyze endogenous and exogenous factors that contribute to or block the process of digital technology implementation in leading public corporations;

- to establish the relationship between factors of influence and business processes based on the construction of a digitalization system model of the public corporate sector.

\section{The study materials and methods}

The theoretical and methodological basis of the study is the provisions of the corporate governance theory, the concept of platform economy, theoretical and methodological achievements of modern economic and managerial scientific schools and individual scientists.

In the process of research, a set of general scientific, specific scientific, and special methods of cognition was used, in particular:

- graphic method, comparison (in the process of identifying patterns and improving business processes due to the digital transformation of public corporations);

- an integrated approach, structural-functional method, systematization (when substantiating indicators and determining factors influencing the processes of digitalization of public corporations);

- logical generalization (to make conclusions).

The information base of the study consisted of data from the Public Statistics Service of Ukraine, data from international rating agencies, analytical information on digital transformation processes, monographic and periodical literature on the research topic, the results of the author's research.

\section{Results of studying the impact of digitalization on the activities of leading public corporations}

5. 1. The analysis of areas to improve the main business processes of leading public corporations as a result of digital transformation

Ukraine is one of the few countries that have more than positive prospects for economic digitalization. Experts of the Ukrainian Institute of the Future estimate the growth of the share of the digital economy in the GDP of the largest countries in the world by 2030 within $50-60 \%$. Whereas in Ukraine, using the forced scenario (3-5 years), the share of the digital economy may be $65 \%$ of GDP [14].

Based on the monitoring of official data, it is established that the public corporate sector in Ukraine has a large number of enterprises compared to other countries. Thus, in 2019 there 
were more than 3.5 thousand state-owned enterprises with a total profit of USD 2.02 billion [15]. For example, in Switzerland, less than 10 companies operate in the public sector, whose activities are related to the postal service, communications network, and electricity system [16]. Analysis of financial and economic activities of state corporations indicates lower profitability and cost-effectiveness than similar indicators of private companies [17]. Differences in performance may be due to the insufficient use of digital technologies in building business processes in public corporations [18]. In turn, according to numerous studies, the level of digitalization is determined primarily by the information openness and transparency of companies [19]. It seems appropriate to note that among stateowned corporations there are leaders in information openness, which gives grounds to claim that they are actively using digital technologies.

Fig. 1 provides information on the main digital technologies used by leading public corporations operating in the basic sectors of the national economy.

ing sector, the digital transformation has led primarily to the optimization of business processes related to remote customer service and information security, as well as electronic document management. In state-owned companies in the field of transport and communications, the digitalization of basic business processes has significantly improved the quality of services through the speed of service, electronic customer identification. Also, it should be noted that the use and development of digital technologies have created conditions for the provision of administrative services through active cooperation with the Center for Administrative Services.

Despite the rapid spread of digital technology, not all state-owned corporations have been actively involved in this process. In this regard, it seems appropriate to single out participants in the public corporate sector with high and low levels of digital maturity.

It is possible to determine the level of digital maturity of the surveyed companies by identifying the components of the digital transformation strategy.

The digital transformaBanking sector:

- iTiny system, ECO BOOM 24/7, EKO-BANK mobile application, POSterminals (JSC Ukrgasbank);

- Mobile banking Oschad 24/7, Google Pay, Apple Pay, MiPay and SwatchPAY, POS-terminals (JSC "Oschadbank"); - Internet banking Privat24, digital banking branch, digital document sharing, POS-terminals (JSC CB "Privatbank").

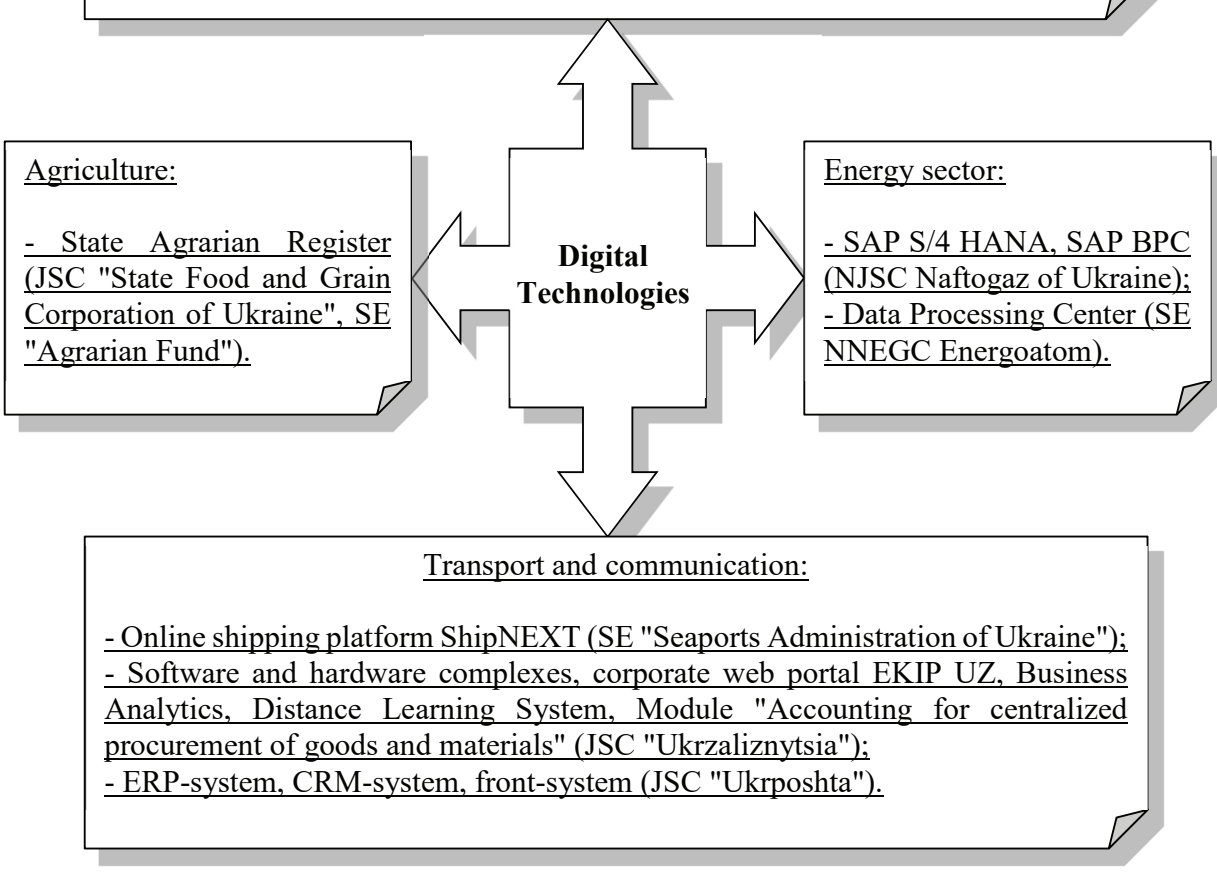

Fig. 1. Digital technologies of the leading public corporations Note: compiled using data from [21-29]

The use of digital technologies by public corporations provides an opportunity to manage business processes more effectively by establishing strong relationships [20]. Thus, after the introduction of digital technologies SAP S/4 HANA and SAP BPC, Naftogaz Ukraine has the opportunity to improve a number of business processes. Among them are the following: tax accounting and reporting, logistics, sales, maintenance and repair, investment and capital construction, controlling, personnel management. In the bank- tion strategy consists of three main components:

1) introduction of digital technologies to the main business processes;

2) introduction of digital technologies to education processes;

3) forming of digital corporate culture [3, 4].

Most public companies are limited to mastering only the first component of the digital transformation strategy, which indicates a low level of their digital maturity. The gradual transition to the second and third components demonstrates the development and achievement of a high level of digital maturity. No less important criterion of digital transformation is the level of information transparency. The level of the transparency index of public corporations is determined according to study [30], which provides a rating of the level of companies' transparency by type of economic activity. It should be noted that among the surveyed state corporations, the highest value of the transparency index in 2019 was in JSC

"Ukrgasbank" (62.5\%), the lowest - SE "State Kyiv Design Bureau" "Luch" (5\%). Identification of two provided characteristics in the leading state corporations creates the basis for building a morphological matrix of digital transformation of state corporations and determining the position of the latter in the study process (Fig. 2).

Based on the results of the matrix evaluation, it can be concluded that digitization processes in corporations-outsiders attract the most attention. This is because this po- 
sition is characterized by a high level of digital maturity but a low level of transparency. In other words, the active digitalization of business processes in these state-owned corporations does not contribute to their information openness. To ensure a high level of transparency, these companies consider it appropriate to introduce new digital technologies.

As an innovative tool that will build a transparent model of business process management and fully meets modern trends in digitalization, it is proposed to use the blockchain [31]. The use of blockchain technology in the electricity sector is becoming especially important, as evidenced by world statistics on its use and the implementation of more than two hundred energy projects. Thus, almost fifty well-known EU energy companies, including Enel (Italy), RWE (Germany), Tennet Holding BV (The Netherlands), all internal business processes, as well as customer service have been transferred to blockchain technology [32].

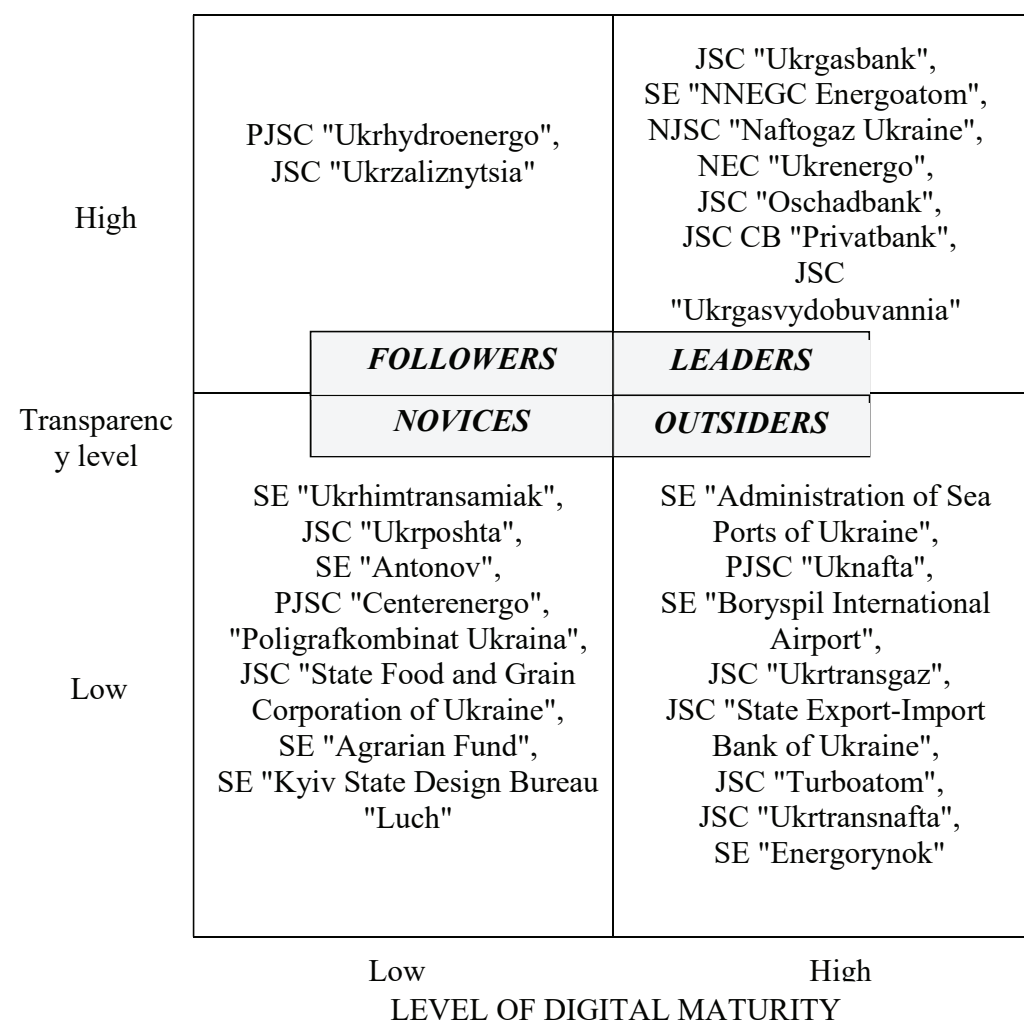

Fig. 2. Morphological matrix of digital transformation of the leading public corporations

Note: compiled using data from [21-30]

The basic scheme of blockchain technology is to generate secure and transparent (accessible to all participants) data on the company's transactions [33]. The main advantage of this digital tool is the reduction of costs by simplifying the business process of "buying and selling", as well as increasing trust through information openness and transparency.

The use of IT outsourcing companies could also be an important tool for digitization. The creation of information technology plays a significant role in the development of the country. More and more agents are doing business in both domestic and international markets unconventionally, which encourages the development of new vectors of cooperation, one of which is IT outsourcing [34]. The rapid development of information and communication technologies allows forming a new type of economy, which scientists call the "digital economy".

5. 2. Studying the management effectiveness indicators of business processes as a result of digitalization

To assess the effectiveness of the digitalization results of companies, different approaches, techniques, and models are used, which are based on a set of indicators.

Traditionally, the DuPont factor model, which contains a system of interrelated financial indicators, is used to assess the effectiveness of any process [35]. A significant benefit of this model is the use of a set of indicators that provide a systematic description of the return on equity and reveal the possibilities of its growth due to the factors present in the model of several levels. The limitation of using the DuPont model to assess the digitalization results of state-owned corporations is a one-sided approach - only the financial aspect of their activities is considered. At the same time, the introduction of digital technologies in the activities of companies can dramatically change almost all business processes.

In this regard, the approach developed by Siemens is interesting, which proposes to assess the digital capabilities of manufacturers in six areas:

1. Data intensity: data strategy, data collection, storage and analysis, and data-based decision making.

2. Connection: use of sensors in production and sales, as well as network connection of production equipment and plants.

3. Adaptation: customization, design, and modeling capabilities, as well as robotics.

4. Integration: integration of enterprise data and supply chain.

5. Security: implementation of strategy and systems.

6. People: leadership, skills, and training [36].

Besides, to assess the results of digital transformation, it is advisable to use a methodology based on strategic maps of the balanced scores system. According to this methodology, the company's efficiency is analyzed in four aspects: finance, customers, business processes, and personnel. Each of these aspects has its system of indicators [37].

A study of state-owned corporations shows that the introduction of digital technologies at the business process level requires significant resources and affects the customer audience. This allowed identifying three main areas for evaluating the results of digitalization - resources, business processes, and customers. At the same time, the system of indicators in the area of "Resources" is proposed to be considered in the financial, informational, and human aspects. The decomposition of indicators that are proposed to be used to assess the results of the digitalization of state corporations is shown in Fig. 3.

Among the above indicators for assessing the results of digitalization of state corporations, only financial ones can be accurately determined, because the definition uses traditional indicators of financial analysis, which are quantitative. Among the indicators in the area of "Customers" can be presented as general marketing indicators. It is worth noting 
that the set of indicators for assessing the results of digitalization of state corporations in each area can be adjusted depending on the specifics of the corporation. prises. The state expenditures on digitalization, laid down in the state budget of Ukraine, are growing every year. At the same time, political instability in the country, lack of unified standards for the use of digital technologies, and insufficient regulation of relations in the field of digitalization create state barriers to digital transformation. The legal support of digitalization processes also needs to be refined and harmonized with modern conditions. In this regard, it should be noted, perhaps, the first in the history of the independent Ukraine proposal of the scientific community to initiate and develop bill No. 4328 "About tokenized assets and cryptocurrencies" [41]. This bill aimed to legalize relations in the field of virtual assets and has already become resonant [42]. Its introduction will cause a significant impetus in the regulation of personal non-property and property relations in the field of digital assets between users of digital data accounting systems, which arise, change, and terminate in transactions in which the digital asset is the subject of agreement and transactions.

Economic instability is manifested in fluctuations in the national currency, inflationary price increases, differences in the economic development of the regions. Also, the level of digitalization is influenced by the type of economic activity. For example, in the field of financial services, communication services, logistics, Ukrainian companies are actively implementing modern information technology. Moreover, private corporations are characterized by a higher

Fig. 3. Evaluation indicators of digitalization results of public corporations Note: compiled using data from [34-38]

\section{3. Analysis of digitalization factors of public cor- porations}

The processes of digital transformation of public corporations are under the active influence of exogenous and endogenous factors [39]. Exogenous factors are caused by external causes, while endogenous factors are related to internal processes occurring in the activities and business processes of state corporations. Dynamic changes in these factors can lead to both acceleration and limitation of digitization.

To identify the directions of influence of exogenous factors on the processes of digitalization of state corporations, it seems appropriate to study trends in the political, legal, economic, scientific, technical, and social spheres.

Under modern conditions, the state provides comprehensive support for digital transformation processes. This is evidenced by the proclaimed 2016 "Digital Agenda of Ukraine", which identifies the next steps and areas of digitalization [40]. In 2018, the Cabinet of Ministers of Ukraine approved the "Concept for the development of the digital economy and society of Ukraine for 2018-2020 and the action plan for its implementation." Accordingly, in 2019 the Ministry of Digital Transformation was established, which has achieved significant results in just a few years of operation. The following are among the results: digitalization of administrative services and expansion of high-speed Internet access, support for the introduction of digital technologies in the activities of state-owned enter- competitive position compared to the public sector. This gives grounds to claim that there are significant limitations in the process of digitalization of state corporations due to the economic factor.

Accelerating scientific and technological development creates the basis for the rapid spread of new business models based on digital platform solutions [43] and digital accounting of property and non-property rights using distributed registry perts, in most Ukrainian enterprises the share of investment costs for the introduction of high-tech products is significantly lower than foreign companies. Thus, in 2017, the total R\&D expenditures of the world's 1000 largest companies amounted to more than USD 700 billion, while in Ukraine this figure was in the range of USD 400-450 million. According to the results of 2018, only $16.4 \%$ of Ukrainian companies were characterized by innovation activity. In contrast, in developed countries, the share of companies that innovate exceeds this figure by $4-5$ times and is 50-60\% [45]. Besides, in Ukraine, there is a so-called digital divide between the center and the periphery. These conditions have a negative impact on the digitalization of public corporations, resulting in an insufficient level of digital solutions, low protection of digital instruments from external influences, lagging the development of digital infrastructure.

The effectiveness of the digital transformation of stateowned corporations in Ukraine is directly related to the general digitalization of Ukrainian society. This is due to technologies (blockchain) [44]. However, according to ex- 
the fact that the main driving force of digitalization is people with certain knowledge, skills, abilities, experience. Performed studies [46] show a low level of public involvement in digitalization processes, due primarily to the age gap in the use of digital technologies and very uneven coverage of urban and rural populations of Ukraine with a quality Internet connection. In other words, a relatively large percentage of the older generation and the rural population are able to actively use digital services, but only if it is accessible from an organizational and technical point of view. According to a 2019 sociological survey of digital skills of the population of Ukraine, more than $50 \%$ of citizens have a lower level of digital skills than baseline, which indicates a low level of digital literacy. At the same time, a positive trend is that almost half of Ukrainians are interested in acquiring digital skills. In addition, the coverage of the population and regions with high-speed Internet access is increasing. Thus, from 2005 to 2018 , the penetration rate of fixed high-speed Internet access per 100 population increased from $0.28 \%$ to $12.8 \%$ [45]. But this figure remains at a level that is twice and sometimes three times less than the level of developed countries. Despite the lag in the digitalization of society, among developed countries, there is a high demand for Ukrainian IT professionals, due to the high level of higher education in this field. In the Ukrainian market of IT specialists, the demand is twice as high as the supply, which creates the basis for its further development, despite the crisis.

Among the endogenous factors that can contribute to the digital transformation of state corporations, it is appropriate to include a developed management system, flexible organizational structure, competent staff, technological equipment, modern models of interaction with consumers [47]. Successful digitization and the avoidance of misunderstandings and resistance to change on the part of individual employees can be ensured when initiatives come directly from the top management of corporations. The digitalization of companies affects the main business processes, as a result of which certain parts of the organizational structure need to be transformed or even eliminated. A flexible organizational structure allows one to speed up the process of digitization of business processes, which provides greater efficiency for companies [48, 49]. Achieving a positive effect from digital transformation in most cases depends on the knowledge, skills, and experience of staff. In addition, the important qualities of employees involved in digitalization processes are openness to new ideas and experiments [50]. Digitalization involves the construction of new schemes of interaction with customers through the active use of digital technologies. To achieve the intended result, it is important for state-owned companies to demonstrate to consumers the benefits of using digital technologies through their training and consulting.

Even though the activities of state-owned companies have created enough drivers for the improvement and development of digital technologies, it is advisable to identify factors that limit the research processes. The barriers to digitalization include, first and foremost, resource barriers, including a lack of funds for the implementation, operation, and maintenance of high-value digital instruments and a lack of qualified personnel. It is worth mentioning the psychological barriers associated with a negative perception of the experience of digital technology in other companies, or awareness of the possibility of further success without the introduction of digital technology.
5. 4. Results of studying interrelationships between impact factors and business processes of digitalization of the public corporate sector

Generalization of indicators of business processes efficiency and criteria of factor conditions of digital transformation allows us to highlight the basic components of the system model of digitalization of the state corporations of Ukraine, namely:

1. Favorable conditions.

2. Resource security.

3. Integration links.

4. Optimized business processes.

5. Information transparency.

6. Economic efficiency.

Considering the above, the system model of digitalization of the public corporate sector $\left(E_{D}\right)$ is as follows:

$$
E_{D}=F\left\{\begin{array}{l}
F C \uparrow\left(P S \uparrow ; G S_{D} \uparrow ; G N P \uparrow ; D I \uparrow ; D L \uparrow\right) \\
R A \uparrow\left(S R \uparrow ; P_{I T} \uparrow ; C E S \uparrow ; F_{O S} \uparrow ; A T \uparrow\right) \\
I C \uparrow\left(I B P \uparrow ; E P \uparrow ; N C \uparrow ; P I \uparrow ; C_{D M} \uparrow\right) \\
O B P \uparrow\left(\begin{array}{l}
T B T \downarrow ; A B T \uparrow ; \\
I B P T \uparrow ; R W \downarrow ; T N P M \downarrow
\end{array}\right) \\
I T \uparrow\left(D D \uparrow ; L I S \uparrow ; A A \uparrow ; C V \uparrow ; I_{T} \uparrow\right) \\
E E \uparrow\left(P \uparrow ; R \uparrow ; C C \uparrow ; E_{D I P} \uparrow ; L P \uparrow\right)
\end{array}\right\},
$$

where $F C$ is the level of the component "Favorable condition"; $P S_{D}$ is the level of digitalization of public services; $G S_{D}$ is the government spending on digitalization; GNP is the GNP volume; $D I$ is the development of digital infrastructure; $D L$ is the digital literacy of the population; $R A$ is the level of the component "Resource access"; $S R$ is sales revenue; $P_{I T}$ is a number of IT experts; $C E S$ is the competence level and staff experience; $F_{O S}$ is flexibility of organization structure; $A T$ is a share of automated technologies; $I C$ is the level of the component "Integration links"; IBP is the level of integration of business processes; $E P$ is the promotion efficiency; $N C$ is the number of new consumers and audience reach; $P I$ is the number of interaction points with a company; $C_{D M}$ is the number of the customers involved to digital communication and marketing channels; $O B P$ is the level of the component "Optimized business processes"; $T B T$ is the time of business operations; $A B T$ is the accuracy of business operations; IPBT is the informational protection of business operations; $R W$ is the level of routine work; TNPM is the time of launching the new products on the market; $I T$ is the level of the component "Information transparency"; $D D$ is the share of digitalized documents; LIS is the level of use of the innovative information systems; $A A$ is the level of analytical activity; $C V$ is the level of customer value; $I_{T}$ is the index of information transparency; $E E$ is the level of the component "Economic efficiency"; $P$ is profitability; $R$ is cost-efficiency; $C C$ is the cost of the company; $E_{D I P}$ is the efficiency of digital investment projects; $L P$ is the work productivity.

To test practically the developed model, a survey of client managers, leading specialists, and managers of various levels of state corporations in the banking sector, including JSC Oschadbank, JSC CB Privatbank, was conducted. A total of 50 experts took part in the survey. Processing the results of the questionnaire made it possible to determine the significance of the components of the model, as well as their indicators (Table 1). 
Table 1 and systematic application of new techniques and

Significance coefficients of components and indicators of the digitalization model of public corporations in the banking sector

\begin{tabular}{|c|c|c|c|}
\hline $\begin{array}{l}\text { Model } \\
\text { compo- } \\
\text { nent }\end{array}$ & $\begin{array}{l}\text { Signifi- } \\
\text { cance co- } \\
\text { efficient }\end{array}$ & Indicator & $\begin{array}{c}\text { Signif- } \\
\text { icance } \\
\text { coefficient }\end{array}$ \\
\hline \multirow{5}{*}{$\begin{array}{l}\text { Favor- } \\
\text { able con- } \\
\text { ditions }\end{array}$} & \multirow{5}{*}{0.15} & Level of digitalization of public services & 0.20 \\
\hline & & Government spending on digitalization & 0.15 \\
\hline & & GNP volume & 0.10 \\
\hline & & Development of digital infrastructure & 0.30 \\
\hline & & Population digital literacy & 0.25 \\
\hline \multirow{5}{*}{$\begin{array}{l}\text { Resource } \\
\text { provision }\end{array}$} & \multirow{5}{*}{0.20} & Sales revenue & 0.20 \\
\hline & & Number of IT specialists & 0.30 \\
\hline & & Staff competence level and experience & 0.15 \\
\hline & & Flexibility of organization structure & 0.10 \\
\hline & & Share of automated technologies & 0.25 \\
\hline \multirow{5}{*}{$\begin{array}{l}\text { Inte- } \\
\text { gration } \\
\text { links }\end{array}$} & \multirow{5}{*}{0.05} & Integration level of business processes & 0.20 \\
\hline & & Promotion efficiency & 0.10 \\
\hline & & Number of new consumers and audience reach & 0.15 \\
\hline & & Number of interaction points with a company; & 0.30 \\
\hline & & $\begin{array}{l}\text { Number of customers involved in digital } \\
\text { channels of communication and marketing }\end{array}$ & 0.25 \\
\hline \multirow{5}{*}{$\begin{array}{c}\text { Opti- } \\
\text { mized } \\
\text { business } \\
\text { processes }\end{array}$} & \multirow{5}{*}{0.20} & Duration of business operations & 0.15 \\
\hline & & Accuracy of business operations & 0.20 \\
\hline & & Informative protection of business operations & 0.30 \\
\hline & & Level of routine work & 0.10 \\
\hline & & Time of new products' launch in the market & 0.25 \\
\hline \multirow{5}{*}{$\begin{array}{l}\text { Infor- } \\
\text { mation } \\
\text { transpar- } \\
\text { ency }\end{array}$} & \multirow{5}{*}{0.25} & Share of digitalized documents & 0.20 \\
\hline & & Level of innovative information systems use & 0.30 \\
\hline & & Level of analytical activity & 0.15 \\
\hline & & Level of the customer's value & 0.10 \\
\hline & & Information transparency index & 0.25 \\
\hline \multirow{5}{*}{$\begin{array}{l}\text { Econom- } \\
\text { ic effi- } \\
\text { ciency }\end{array}$} & \multirow{5}{*}{0.15} & Profitability & 0.25 \\
\hline & & Cost-efficiency & 0.20 \\
\hline & & Cost of the company & 0.15 \\
\hline & & Effectiveness of digital investment projects & 0.30 \\
\hline & & Productivity & 0.10 \\
\hline
\end{tabular}

methods of management [51, 52].

The conducted study identifies the types of diversity of digital control technologies. Therefore, it seems clear, logical, and effective structuring of digital tools, provided in [1], which presents the place of digital transformation drivers and their applications. However, in contrast to [1], where the main emphasis is on digitalization of management subsystems (organization, customers and sales, finance), in this study digital technologies are generalized to the basic sectors of the national economy (Fig. 1). Also, the approach is quite original, according to which the leading stateowned corporations are combined into four groups according to the criteria of digital maturity and transparency levels (Fig. 2).

Further research necessitates substantiation of the use of each of the digital tools in the process of improving the efficiency of public corporations, including in terms of business processes and desired results in the overall management system.

It is worth noting that the evaluation indicators of the digitalization results of public corporations (Fig. 3) provide a basis for solving the problem posed in the study. The need to introduce methods of information and digital transformation in the management of state property is emphasized in studies [53, 54]. Analyzing the concept of state corporation management on the principles of digital tools, $[9,55]$ emphasizes the fact that this process should be based on numerous information flows that require the introduction of appropriate processing methods. However, the advantage of the proposed areas of evaluation of digitization results in comparison with existing evaluation methods is the use of an integrated approach.

The analysis of the operating conditions of state-owned corporations has shown that they are actively influenced by other economic actors, governments at various levels, resource markets,

Most indicators of the model have the appropriate quantitative expression, some of them can be measured in points by the expert way. Thus, after the implementation of the procedure of indicators normalization, it is possible to calculate individual indices (for each component of the model) and the integrated index of digitalization of the public corporate sector.

The proposed algorithm seems appropriate to use both in the conditions of a separate state corporation and the conditions of activity of public corporations in a certain sector of the national economy. This will make it possible to compare and determine the effect of the introduction of digital technologies in the public corporate sector.

\section{Discussion of results of studying the digitalization impact on the activity of leading public corporations}

Analysis of the improvement directions of the main business processes of leading public corporations due to the digital transformation proves that the state corporation has a set of competitive benefits. This allows for new trajectories of further development, which, in turn, involve the formation consumer demand, other actors, and processes outside the national economy. This gives grounds to claim that they are important elements of the national economic system, which naturally have a mutual influence of both positive and negative nature. Considering the number of links between these elements of the national economy based on research [56, 57], groups of factors have been identified that influence the procedure and features of digitalization of state-owned corporations. The obtained results suggest that the main exogenous factors hindering and inhibiting the implementation of digital transformations are related to the unstable general political and economic situation. It is also worth noting the impact of competitors' actions due to the commitment to traditional management tools to retain the final consumer, technological barriers in the form of insufficient infrastructure development, the presence of illegal or pirated software, copyright and intellectual property infringement, and the slow pace of "digital" implementation. Endogenous factors that hinder the implementation of the digitalization principles of management of public corporations include, first of all, resource constraints. They may be related to the cost of purchasing and using digital technologies, as well as the lack of qualifications of the company's staff who will 
use software products [58]. In addition, the introduction of new technologies will require changes or destruction of the historical infrastructure of the enterprise.

Based on the generalization of the impact criteria, a digitalization system model of the public corporate sector has been developed, which contains five indicators for each of the six components. The components of the system model are favorable conditions, resource security, integration links, optimized business processes, information transparency, economic efficiency. The limitation of the proposed method of evaluation in practice is the impossibility of quantifying individual indicators of the model, as well as determining the level of significance of indicators and components of the model. However, the problem can be solved with the perfect selection of experts for evaluation.

Besides, since digitalization creates the preconditions for improving the efficiency of state-owned corporations, the question arises as to the choice of criteria for assessing this impact. Research shows that at the corporate level, the main effect of digital transformation is to increase the level of information openness and transparency. This approach is somewhat limited because a large number of indicators, factors, and trends remain not considered and need further development.

The development of further research will consist in deepening theoretical and methodological work on improving the efficiency of state corporations. Public corporations are just a kind of "form" of trust management of people's property and national wealth. Accordingly, it is expected to increase the efficiency of public corporations through the introduction of digital tools in key business processes. Among which a special place is given to the processing of big data; accounting and operational management of tangible and financial assets based on digital information platforms using secure private registers on the blockchain and digital assets. To this end, the authors will continue to develop the concept of "management of public values" [59,60] and the methodology of the platform economy and platform governance "Government as a Platform" (government as a platform, GaaP) for the needs of state corporations in Ukraine. In turn, this will methodologically strengthen the emphasis on collective management, responsible and inclusive governance, and the ability to achieve new societal values and public benefit through new digital means. In addition, more detailed prospects for further research are related to:

- in-depth identification of relevant indicators and relationships that were not included in the system model of digitalization of state corporations;

- clarification of theoretical and methodological provisions on the decomposition of factors influencing the process of digital transformation of state corporations with the definition of the direction and level of their influence. It aims to identify the digital tools and technologies of public corporations that are most optimal in specific economic conditions and increase the overall performance of their activities.

\section{Conclusions}

1. Based on the generalization of the experience of public corporations of Ukraine, digital technologies are systematized by sectors of the national economy and the main business processes are identified that are improved as a result of digital transformation. It is proved that in the conditions of global market development the main criterion of successful digitalization of the public corporate sector is "information openness and transparency", as a result of which there are qualitative changes in the business process management system of corporations. To determine the position of state corporations in the study process, it is proposed to use the morphological matrix of digital transformation. The expediency of the introduction of new digital technologies for the construction of a transparent model of business process management is substantiated. It is proposed to use the blockchain as a modern trend of digitalization, which will create a basis for improving the efficiency of state corporations.

2 . The necessity of evaluating the effectiveness of digitalization results in the development of corporate development strategy in the context of globalization is proved. The scientific and methodological approach to the evaluation of the results of digitalization of state corporations, which involves the formation of the indicators' system in three directions: resources, business processes, and customers. It is established that a public corporation by its nature and original design is an artificially created trusted agent that should conduct operational management of national resources (property and natural resources) in the interests of the owner (the people). Thus, the integrated use of digital technologies can significantly (radically) change the forms and consequences of such operational management, which is carried out on behalf of the state and, most importantly - the people as the ultimate owner and beneficiary of such management. According to the critical operational inefficiencies of most state-owned corporations (rising administrative costs and annual losses), the introduction of digital technologies is particularly relevant. Their use will provide not so much greater efficiency but a higher level of trust between the owner of the asset (the people) and the agent (state corporation). These are distributed registry (blockchain) technologies and digital solutions based on them: decentralized platforms and tokenized and digital assets. Organized on the model of government as a platform (GaaP), together they allow us to create additional public value and mobilize public and private resources to arrange different configurations of public services.

3 . The factor conditions influencing the efficiency of the digitization process are systematized, among which is proposed the separation of factors by external (exogenous) and internal (endogenous) direction of influence. Based on the analysis of political, economic, technological, and social conditions, it is proved that in modern conditions a relatively favorable situation has been created to intensify the process of digital transformation of state corporations, despite numerous barriers from exogenous factors. It has been established that the resource capabilities of corporations can act as a powerful driver for accelerating the introduction of digital technologies of an endogenous nature. At the level of public corporations, it was found that there are significant resource constraints, which are reflected in the lack of funds for the introduction of digital technologies, as well as psychological barriers associated with the reluctance to use digital technologies in the process. This gives grounds to say that the intensification of the digitalization process of the public corporate sector requires a comprehensive effort of the authorities and management.

4. The obtained results provided the basis for the development of a digitalization system model of the public corporate sector of Ukraine based on the identification of the relationship between factors and indicators of business process management efficiency. Understanding the state corporation as a complex system, and the process of digita- 
lization as the main prerequisite for improving its efficiency allowed us to identify six hierarchical levels of the model. These are favorable conditions, resource security, integration connections, optimized business processes, information transparency, economic efficiency. It is established that only the joint interaction of all elements of the digitalization model of the public corporate sector can create the conditions for the success of the digital transformation.

\section{References}

1. Strutynska, I., Dmytrotsa, L., Kozbur, H. (2019). The Main Barriers and Drivers of the Digital Transformation of Ukraine Business Structures. Proceedings of the 15th International Conference on ICT in Education, Research and Industrial Applications. Integration, Harmonization and Knowledge Transfer, 2387, 50-64.

2. Strutynska, I., Kozbur, G., Dmytrotsa, L., Sorokivska, O., Melnyk, L. (2019). Influence of Digital Technology on Roadmap Development for Digital Business Transformation. 2019 9th International Conference on Advanced Computer Information Technologies (ACIT). doi: https://doi.org/10.1109/acitt.2019.8780056

3. Saarikko, T., Westergren, U. H., Blomquist, T. (2020). Digital transformation: Five recommendations for the digitally conscious firm. Business Horizons, 63 (6), 825-839. doi: https://doi.org/10.1016/j.bushor.2020.07.005

4. Jones, M. D., Hutcheson, S., Camba, J. D. (2021). Past, present, and future barriers to digital transformation in manufacturing: A review. Journal of Manufacturing Systems, 60, 936-948. doi: https://doi.org/10.1016/j.jmsy.2021.03.006

5. Dillon, S. M., Glavas, C., Mathews, S. (2020). Digitally immersive, international entrepreneurial experiences. International Business Review, 29 (6), 101739. doi: https://doi.org/10.1016/j.ibusrev.2020.101739

6. Jafari-Sadeghi, V., Garcia-Perez, A., Candelo, E., Couturier, J. (2021). Exploring the impact of digital transformation on technology entrepreneurship and technological market expansion: The role of technology readiness, exploration and exploitation. Journal of Business Research, 124, 100-111. doi: https://doi.org/10.1016/j.jbusres.2020.11.020

7. Shakina, E., Parshakov, P., Alsufiev, A. (2021). Rethinking the corporate digital divide: The complementarity of technologies and the demand for digital skills. Technological Forecasting and Social Change, 162, 120405. doi: https://doi.org/10.1016/j.techfore.2020.120405

8. Lobschat, L., Mueller, B., Eggers, F., Brandimarte, L., Diefenbach, S., Kroschke, M., Wirtz, J. (2021). Corporate digital responsibility. Journal of Business Research, 122, 875-888. doi: https://doi.org/10.1016/j.jbusres.2019.10.006

9. Kud, A., Mashchenko, M., Pypenko, I., Soboleva, I. (2020). Predicting the Impact of Digital Assets on Socioeconomic Development of an Enterprise. Kharkiv: KRPOCH, 67. doi: https://doi.org/10.26697/9786177089116.2020

10. Sama, L. M., Stefanidis, A., Casselman, R. M. (2021). Rethinking governance for the digital era: The role of stewardship. Business Horizons. doi: https://doi.org/10.1016/j.bushor.2021.08.001

11. Kud, A. (2021). Decentralized information platforms as a tool of public governance modernization. "Bulletin of Postgraduate Education" (Series «Social and Behavioural Sciences»), 15 (44), 233-274. doi: https://doi.org/10.32405/2522-9931-2021-15(44)-233-274

12. Ispol'zovanie tekhnologii blokcheyn $\mathrm{v}$ tselyah ustoychivogo razvitiya: perspektivy i problemy (2021). Ekonomicheskiy i Sotsial'nyy Sovet. Available at: https://unctad.org/system/files/official-document/ecn162021d3_ru.pdf

13. Intersessional panel of the United Nations Commission on science and technology for development (CSTD): Contribution by Latvia to the CSTD 2020-2021 priority theme on "Harnessing blockchain for sustainable development: prospects and challenges" (2020). Geneva, 5. Available at: https://unctad.org/system/files/non-official-document/CSTD_2020-21_c21_B_Latvia_en.pdf

14. Ukraina 2030E - kraina z rozvynutoiu tsyfrovoiu ekonomikoiu (2019). Available at: https://strategy.uifuture.org/kraina-zrozvinutoyu-cifrovoyu-ekonomikoyu.html

15. OECD (2021). OECD Review of the Corporate Governance of State-Owned Enterprises in Ukraine. Available at: https:// www.oecd.org/corporate/ca/soe-review-ukraine.htm

16. Public sector achievement in 36 countries (2015). A comparative assessment of inputs, outputs and outcomes. Available at: https:// www.eupan.eu/wp-content/uploads/2019/02/2016_1_NL_Public_Sector_Achievement_in_36_Countries.pdf

17. Markevych, K. (2017). Derzhavni VS pryvatni. Visnyk Ofitsiyno pro podatky, 3-4 (6). Available at: http://www.visnuk.com.ua/uk/ publication/100005791-derzhavni-vs-privatni-1

18. Chen, X., Dai, Q., Na, C. (2019). The value of enterprise information systems under different corporate governance aspects. Information Technology and Management, 20 (4), 223-247. doi: https://doi.org/10.1007/s10799-019-00310-3

19. Canhoto, A. I., Quinton, S., Pera, R., Molinillo, S., Simkin, L. (2021). Digital strategy aligning in SMEs: A dynamic capabilities perspective. The Journal of Strategic Information Systems, 30 (3), 101682. doi: https://doi.org/10.1016/j.jsis.2021.101682

20. Hinings, B., Gegenhuber, T., Greenwood, R. (2018). Digital innovation and transformation: An institutional perspective. Information and Organization, 28 (1), 52-61. doi: https://doi.org/10.1016/j.infoandorg.2018.02.004

21. Hrupa Naftohaz zdiysniuie kompleksnu tsyfrovu transformatsiu dlia zabezpechennia prozorosti biznesu ta pidvyshchennia kapitalizatsiyi. Available at: https://news.sap.com/ukraine/2021/02/naftogaz-s4hana/

22. Stvorennia tsentriv obrobky danykh poblyzu AES zabezpechyt Enerhoatomu postiinoho spozhyvacha elektroenerhiyi. Available at: https://www.atom.gov.ua/ua/press_centr-19/novini_kompanii-20/p/stvorenna_centriv_obrobki_danih_poblizu_aes_ zabezpecit_energoatomu_postijnogo_spozivaca_elektroenergii-46004 
23. Obruch, A. (2019). Organizational and resource support digital transformation of railway transport. Intellect XXI, 6, 138-143. doi: https://doi.org/10.32782/2415-8801/2019-6.25

24. Ukrposhta, Mininfrastruktury ta Mintsyfry uklaly memorandum pro spivpratsiu (2020). Available at: https://www.ukrposhta.ua/ ua/news/57204-ukrposhta-mininfrastrukturi-ta-mincifri-uklali-memorandum-pro-spivpracju

25. Oleshko, T., Popyk, N., Babych, M. (2021). Digitalization of business processes in civil aviation. Ekonomika Ta Derzhava, 4, 43-46. doi: https://doi.org/10.32702/2306-6806.2021.4.43

26. AMPU ta SHIPNEXT stvoriat systemu tsyfrovoho obminu danymy dlia suden ta portiv. Available at: http://www.uspa.gov.ua/ ru/pres-tsentr/novini/novini-ampu/17099-ampu-ta-shipnext-stvoryat-sistemu-tsifrovogo-obminu-danimi-dlya-suden-ta-portiv

27. Kloba, L. H. (2018). Digitization is innovative to the development of banks. Efektyvna Ekonomika, 12. doi: https://doi.org/ 10.32702/2307-2105-2018.12.84

28. Serhiy Naumov: «Bankivska systema - dzerkalo ekonomiky. Pohliad u maibutnie». Available at: https://www.oschadbank.ua/news/ sergij-naumov-bankivska-sistema-dzerkalo-ekonomiki-poglad-u-majbutne

29. Vodianka, L., Yurii, T. (2020). Digitalization and digital platform in the economic development of the agricultural sector. Ekonomika APK, 12, 67-73. doi: https://doi.org/10.32317/2221-1055.202012067

30. Indeks prozorosti kompaniy Ukrainy. Available at: https://index.cgpa.com.ua/

31. Erol, I., Ar, I. M., Ozdemir, A. I., Peker, I., Asgary, A., Medeni, I. T., Medeni, T. (2020). Assessing the feasibility of blockchain technology in industries: evidence from Turkey. Journal of Enterprise Information Management, 34 (3), 746-769. doi: https:// doi.org/10.1108/jeim-09-2019-0309

32. Enerhetyka Ukrainy: vyklyky ta initsiatyvy (2020). Kyiv. Available at: https://razumkovenergy/meny/research/energetika-ukra \%D1\%97ni-vikliki-ta-inicziativi.html

33. Sung, C. S., Park, J. Y. (2021). Understanding of blockchain-based identity management system adoption in the public sector. Journal of Enterprise Information Management, 34 (5), 1481-1505. doi: https://doi.org/10.1108/JEIM-12-2020-0532

34. Pererva, P., Kuchynskyi, V., Kobielieva, T., Kosenko, A., Maslak, O. (2021). Economic substantiation of outsourcing the information technologies and logistic services in the intellectual and innovative activities of an enterprise. Eastern-European Journal of Enterprise Technologies, 4 (13 (112)), 6-14. doi: https://doi.org/10.15587/1729-4061.2021.239164

35. Model' Dyupona (DuPont). Available at: https://allfi.biz/financialmanagement/FinancialStatementsAnalysys/model-dupont.php

36. Digital Intensity in US Manufacturing (2017). Siemens. Available at: https://www.supplychain247.com/paper/digital_intensity_ in_us_manufacturing/manufacturing

37. Kaplan, R. S., Norton, D. P. (2016). Sbalansirovannaya sistema pokazateley. Ot strategii k deystviyu. Moscow: Olimp-Biznes, 320.

38. Caliskan, A., Özkan Özen, Y. D., Ozturkoglu, Y. (2020). Digital transformation of traditional marketing business model in new industry era. Journal of Enterprise Information Management, 34 (4), 1252-1273. doi: https://doi.org/10.1108/jeim-02-2020-0084

39. Kaufman, I., Horton, C. (2015). Digital transformation: Leveraging digital technology with core values to achieve sustainable business goals. The European Financial Review, 63-67. Available at: https://www.academia.edu/9964924/Digital_Transformation

40. Tsyfrova adzhenda Ukrainy - 2020 (2016). Available at: https://ucci.org.ua/uploads/files/58e78ee3c3922.pdf

41. Proekt Zakonu pro tokenizovani aktyvy ta kryptoaktyvy. No. 4328 vid 05.11.2020. Verkhovna Rada Ukrainy. Available at: http:// w1.c1.rada.gov.ua/pls/zweb2/webproc4_1?pf3511=70353

42. International roundtable "Virtual assets in the development of national economy". Available at: https://conf2021.blockchainukraine.org

43. Kud, A. A. (2021). Formation of public value based on existing platform solutions in the public sector. Aktualni problemy derzhavnoho upravlinnia, 1 (59), 51-67. Available at: http://ap.kh.ua/index.php/apdu/article/view/453/614

44. Dmytryk, O. O., Kostenko, Y. O., Monaienko, A. O., Riadinska, V. O., Soldatenko, O. V. (2020). State Legal Forms of Interaction with Debt Obligations and State Losses. Journal of Advanced Research in Law and Economics, 11 (2), 342. doi: https://doi.org/10.14505/ jarle.v11.2(48).07

45. Tsyfrova ekonomika: trendy, ryzyky ta sotsialni determinanty (2020). Kyiv, 274.

46. Dunayev, I., Kud, A. (2020). Developing digital skills and competencies of Ukrainian specialists as a vital need in the global digital transformation era. Pressing Problems of Public Administration, 1 (57), 8-17. doi: https://doi.org/10.34213/ap.20.01.01

47. Dunayev, I.; Tavidze, A. (Ed.) (2018). The modernization logics and principles of designing a new generation of regional economic policies: findings for recent Ukraine and Eastern-European countries in transition, Modernization: Progress in Economics Research. Vol. 41. New York: NOVA Publ., 53-90.

48. Ansong, E., Boateng, R. (2019). Surviving in the digital era - business models of digital enterprises in a developing economy. Digital Policy, Regulation and Governance, 21 (2), 164-178. doi: https://doi.org/10.1108/dprg-08-2018-0046

49. Bouwman, H., Nikou, S., Molina-Castillo, F. J., de Reuver, M. (2018). The impact of digitalization on business models. Digital Policy, Regulation and Governance, 20 (2), 105-124. doi: https://doi.org/10.1108/dprg-07-2017-0039

50. Dussart, P., van Oortmerssen, L. A., Albronda, B. (2021). Perspectives on knowledge integration in cross-functional teams in information systems development. Team Performance Management: An International Journal, 27 (3/4), 316-331. doi: https://doi.org/10.1108/tpm11-2020-0096 
51. Marchenko, V. (2017). Efficiency of deployment of resources in the process of mergers and acquisitions of corporations. Formuvannia rynkovykh vidnosyn v Ukraini, 1 (188), 51-55. Available at: http://nbuv.gov.ua/UJRN/frvu_2017_1_11

52. Chernelevschyj, L., Solomchuk, L. (2015). Corporation as a model of effective business. Intelekt XXI, 2, 54-63. Available at: http:// nbuv.gov.ua/UJRN/int_XXI_2015_2_7

53. Pavlenko, V., Rudchenko, A. (2016). Improvement of efficiency of state property objects management. Formuvannia rynkovykh vidnosyn v Ukraini, 4, 7-12. Available at: http://nbuv.gov.ua/UJRN/frvu_2016_4_4

54. Rudenko, M. (2019). Osoblyvosti formuvannia mekhanizmu tsyfrovizatsiyi upravlinnia v silskohospodarskykh pidpryiemstvakh. Visnyk LNAU: Ekonomika APK, 26, 20-28. doi: https://doi.org/10.31734/economics2019.26.020

55. Voskoboeva, O., Goloborodko, A. (2019). Classification of information logistic flows of process-system approach of enterprise management in the conditions of digitalization of economic processes. Economy. Management. Business, 4 (30), 47-53, doi: https:// doi.org/10.31673/2415-8089.2019.044753

56. Brechko, O. (2020). Determinants of digital transformation of the national economy. Herald of Ternopil National Economic University, 4, 7-24. doi: https://doi.org/10.35774/visnyk2020.04.007

57. Gudz, O. (2018). Digital economy: changing values and guidelines enterprise management. Economy. Management. Business, 2, 4-12. Available at: http://nbuv.gov.ua/UJRN/ecmebi_2018_2_3

58. Dunayev, I., Latynin, M., Ulyanchenko, Y., Kosenko, A. (2019). Renewing an economic policy for a rising Ukrainian region: smoothing discrete shifts and mastering new competencies. Regional science inquiry, XI (3), 133-150. Available at: http:// www.rsijournal.eu/ARTICLES/December_2019/11.pdf

59. Benington, J., Moore, M. (Eds.) (2011). Public value: theory and practice. Basingstoke: Palgrave Macmillan, 314.

60. O’Flynn, J. (2007). From New Public Management to Public Value: Paradigmatic Change and Managerial Implications. Australian Journal of Public Administration, 66 (3), 353-366. doi: https://doi.org/10.1111/j.1467-8500.2007.00545.x 